\title{
POSTĘPOWANIE ADMINISTRACYJNE W SPRAWIE WYMIERZENIA ADMINISTRACYJNEJ KARY PIENIĘŻNEJ W PRAWIE OCHRONY ŚRODOWISKA
}

\section{ADMINISTRATIVE PROCEEDINGS INVOLVING THE IMPOSITION OF ADMINISTRATIVE FINANCIAL PENALTY IN ENVIRONMENTAL PROTECTION LAW}

\section{STRESZCZENIE}

Środowisko jest dobrem wspólnym wszystkich obywateli. Odpowiedzialność za jego naruszenie przewiduje już Konstytucja Rzeczypospolitej Polskiej. Ustawa Prawo ochrony środowiska zawiera natomiast uszczegółowienie tej odpowiedzialności. Reguluje ona nakładanie na 
podmioty korzystające ze środowiska administracyjnych kar pieniężnych. Ustawodawca wprowadził jednak możliwość odroczenia nałożonej kary, a nawet jej umorzenie. Artykuł traktuje o postępowaniu w sprawie wymierzenia administracyjnej kary pieniężnej przewidzianej w art. 298 ust. 1 tej ustawy.

\section{Słowa kluczowe}

Prawo ochrony środowiska; administracyjne kary pieniężne; odpowiedzialność; podmiot korzystający ze środowiska.

\section{ABSTRACT}

The environment is the common good of all citizens. The liability for its violation is already provided for in the Constitution of Poland. The Act on Environmental Protection Law specifies this liability. It regulates the imposition of administrative financial penalties on entities using the environment. However, the legislator introduced a possibility of the penalty postponement or even its remission. The article discusses the proceedings involving the imposition of financial penalties provided for in article 298 section 1of the Act on Environmental Protection Law.

\section{Keywords}

Environmental protection law; administrative financial penalties; liability; entity using the environment.

\section{WPROWADZENIE}

Środowisko jest dobrem wspólnym wszystkich obywateli i prawo do korzystania z niego przysługuje każdemu. Jednakże jeszcze do niedawna jakiekolwiek straty ponosiło całe społeczeństwo. Dlatego zaczęto dążyć do wypracowania środków, których stosowanie spowodowałoby przypisywanie negatywnych efektów zewnętrznych na rachunek ekonomiczny konkretnych sprawców ${ }^{1}$.

1 Por. M. Górski (red.), Prawo ochrony środowiska, Warszawa 2014, s. 145 . 
W ustawie z 27 kwietnia 2001 roku Prawo ochrony środowiska $^{2}$ w Tytule VI, ustawodawca przewidział trzy rodzaje odpowiedzialności za niewykonywanie bądź nieprawidłowe wykonywanie obowiązków związanych z ochroną środowiska, tj. odpowiedzialność cywilną, karną i administracyjną. Pojęcie odpowiedzialności nie zostało w ustawie zdefiniowane. Jednak wzmiankę o nim znajdziemy już w Konstytucji Rzeczpospolitej Polskiej 2 kwietnia 1997 r. ${ }^{3}$ w art. 86, który stanowi, iż każdy jest obowiązany do dbałości o stan środowiska i ponosi odpowiedzialność za spowodowane przez siebie jego pogorszenie. Natomiast art. $77 \mathrm{w}$ ustępie 1 stanowi, że każdy ma prawo do wynagrodzenia za szkodę, jaka została mu wyrządzona przez niezgodne $\mathrm{z}$ prawem działanie organu władzy publicznej. Przepisy te odnoszą się do odpowiedzialności administracyjnej na gruncie prawa ochrony środowiska. Kamila Kwaśnicka wskazuje, że pierwszy z przytoczonych przepisów dotyczy odpowiedzialności podmiotów administrowanych, tj. osób fizycznych, prawnych, jednostek organizacyjnych nieposiadających osobowości prawnej, każdego podmiotu korzystającego z zasobów środowiska. Drugi natomiast do odpowiedzialności podmiotów administrujących. Tym samym odpowiedzialność administracyjną $\mathrm{w}$ rozumieniu prawa ochrony środowiska reguluje art. 86 ustawy zasadniczej ${ }^{4}$. Przepisy dotyczące odpowiedzialności administracyjnej, zawarte w ustawie Prawo ochrony środowiska, są zatem uszczegółowieniem przepisów konstytucyjnych. Nie należy zapominać, że dbanie o środowisko jest obowiązkiem każdego obywatela, o czym dobitnie świadczy treść Konstytucji RP.

2 Dz.U., 2013 r., poz. 1232 ze zm.

3 Konstytucja Rzeczpospolitej Polskiej z dnia 2 kwietnia 1997 r., Dz.U. nr 78, poz. 483 ze zm.

4 K. Kwaśnicka, Odpowiedzialność administracyjna $w$ prawie ochrony środowiska, Warszawa 2011, s. 49-50. 


\section{POJĘCIE ODPOWIEDZIALNOŚĆ ADMINISTRACYJNEJ}

W doktrynie prawa ochrony środowiska znajdziemy wiele definicji odpowiedzialności administracyjnej, które są do siebie bardzo podobne, różnią je jedynie niuanse. Najpopularniejszą definicją odpowiedzialności w prawie ochrony środowiska w ogóle jest definicja W. Langa, który określa odpowiedzialność występującą na gruncie prawa ochrony środowiska, jako ponoszenie przez dany podmiot ujemnych konsekwencji przewidzianych przez to prawo $\mathrm{w}$ związku ze zdarzeniami lub stanami, które podlegają ujemnej kwalifikacji prawnej5. Natomiast samą odpowiedzialność administracyjną J. Ciechanowicz-McLean definiuje jako „uregulowaną prawem możliwość uruchomienia wobec określonego podmiotu naruszającego stan środowiska środków prawnych realizowanych w swoistych dla administracji formach i procedurze"6. Podobny pogląd prezentują J. Boć i E. Samborska-Boć7. Natomiast A. Lipiński definiuje odpowiedzialność administracyjną jako „ustalone przez organ administracji publicznej nakazy (zakazy) określonego zachowania się, zwłaszcza dotyczące: wstrzymania działalności, cofnięcia (ograniczenia zakresu) decyzji zezwalającej na określony sposób korzystania ze środowiska (jego zasobów), wykonania stosownych urządzeń ochronnych, usunięcia stwierdzonych uchybień czy też ich szkodliwych następstw ustanawianych przeważnie w razie ustalenia naruszonych wymagań"s. Jest to definicja, która w sposób najbardziej obrazowy prezentuje odpowiedzialność administracyjną na gruncie prawa ochrony środowiska. Osobiście skłaniam się ku definicji prof. J. Ciecha-

5 W. Lang, Struktura odpowiedzialności prawnej, „Zeszyty Naukowe Uniwersytetu Mikołaja Kopernika”, z. 31 - Prawo VIII, Toruń 1968, s. 12, za: Z. Bukowski, E.K. Czech, K. Karpus, B. Rakoczy, Prawo ochrony środowiska, Komentarz, Warszawa 2013, s. 588.

6 J. Ciechanowicz-McLean, Ochrona środowiska $w$ działalności gospodarczej, Warszawa 2003, s. 29-30.

7 Por. K. Kwaśnicka, Odpowiedzialność..., s. 51.

8 A. Lipiński, Prawne podstawy ochrony środowiska, Kraków 2005, s. 415, za: K. Kwaśnicka, Odpowiedzialność..., s. 51. 
nowicz-McLean, gdyż zawiera ona istotę odpowiedzialności administracyjnej oraz podkreśla, iż, jak sama nazwa wskazuje, odpowiedzialność ta musi być egzekwowana środkami, jakie udostępnia nam procedura administracyjna. Warto przytoczyć także definicję E. Radziszewskiego, według której odpowiedzialność administracyjna jest to stosowanie środków administracyjnych $\mathrm{w}$ celu przestrzegania właśnie prawa administracyjnego i prawa ochrony środowiska w szczególności ${ }^{9}$, a także przepisów konstytucyjnych, o czym była mowa wyżej. W doktrynie prawa ochrony środowiska można spotkać się z poglądami, iż wyróżnienie odpowiedzialności administracyjnej nie jest konieczne. Instrumenty, które obejmuje ona swoim zasięgiem mogłyby wchodzić w zakres odpowiedzialności cywilnej. Jednakże są elementy, które odróżniają odpowiedzialność administracyjną od dwóch pozostałych, czyniąc przez to jej uregulowanie w prawie ochrony środowiska zasadnym. W odróżnieniu od odpowiedzialności cywilnej, odpowiedzialność administracyjna chroni interes publiczny a nie prywatny. Zdeterminowana jest na osiąganie celów związanych właśnie z ochroną środowiska, a nie jak w przypadku odpowiedzialności karnej na prewencję ogólną i szczególną wobec konkretnego sprawcy. Jak zauważa J. Stelmasiak, ,inaczej niż w prawie karnym, podmiot odpowiada tylko za skutek swojego działania, bez względu na istnienie winy lub jej brak. Trzeba więc podkreślić, że odpowiedzialność administracyjna $\mathrm{w}$ ochronie środowiska występuje niezależnie od winy danego podmiotu, a przesłanką jej zastosowania jest obiektywnie ujęte bezprawie administracyjne"10. Należy też pamiętać, że poniesienie przez określony podmiot np. odpowiedzialności karnej nie zwalnia go z odpowiedzialności cywilnej czy właśnie administracyjnej. Każdy rodzaj wymienionej przez ustawodawcę odpowiedzialności posługuje się odrębnymi instrumentami prawnymi oraz spełnia odrębną rolę.

9 Ibidem, s. 51.

10 J. Stelmasiak, K. Popik-Muzyka, Administracyjna kara pieniężna $w$ ustawie Prawo ochrony środowiska, „Ochrona Środowiska. Przegląd” 2002, nr 1, s. 13, za: pod red. J. Stelmasiak, Prawo ochrony środowiska, Warszawa 2009, s. 195. 


\section{ADMINISTRACYJNE KARY PIENIĘŻNE, ICH CHARAKTER PRAWNY ORAZ PRZESŁANKI}

Charakter prawny administracyjnych kar pieniężnych jest tematem niezwykle szerokim i w doktrynie prawa ochrony środowiska budzi wiele kontrowersji. Z racji tego, że kary pieniężne są ujemnym aspektem działalności gospodarczej pojawiły się m.in. głosy, iż wprowadzenie administracyjnych kar pieniężnych wprowadza jednocześnie odpowiedzialność karną osób prawnych ${ }^{11}$. L. Jastrzębski twierdzi natomiast, iż karę pieniężną rozpatrywać można w charakterze nawiązki, ponieważ rekompensuje wyrządzone szkody i poniesione straty ${ }^{12}$. Pojęcie kompensacji oznacza zrównoważenie określonego działania innym działaniem, które znosi lub wyrównuje początkowe działanie. Jak się później przekonamy przy omawianiu administracyjnych kar pieniężnych, teoria kompensacji nie jest całkowicie pozbawiona sensu. Istotnym jest też fakt, o którym pisałam już wyżej, a który poniekąd potwierdza przytoczoną tezę, iż administracyjna kara pieniężna, jako sankcja odpowiedzialności administracyjnej w prawie ochrony środowiska, ma na celu przede wszystkim ochronę interesu publicznego. Dyskusji nie powinien podlegać fakt, iż administracyjna kara pieniężna jest sankcją za nieprzestrzeganie przepisów prawa zawartych w Konstytucji oraz ustawach szczegółowych. Według W. Radeckiego próżno jest szukać różnic w pojęciach „odpowiedzialność administracyjna” i „sankcja administracyjna” - odpowiedzialność jest to bowiem stosowanie sankcji ${ }^{13}$. W związku z powyższym, jeżeli w ramach odpowiedzialność administracyjnej organ administracji publicznej nakłada karę pieniężną jest ona sankcją. Administracyjna kara pieniężna jest również obok opłat instrumentem

11 L. Tyszkiewicz, Problem odpowiedzialności karnej osób prawnych (zakładów pracy) $w$ polskim systemie prawnym, „Prace Naukowe Uniwersytety Śląskiego", nr 54, Katowice 1974, s. 170-171, za: W. Radecki, Opłaty i kary pieniężne $w$ prawie ochrony środowiska. Komentarz do przepisów ustaw, Warszawa 2009, s. 34.

2/2014 12 Ibidem, s. 34.

13 Ibidem. s. 36. 
finansowym, jakie przewiduje prawo ochrony środowiska. Jak piszą A. Jaworowicz-Rudolf i M. Górski instrumenty te mogą z powodzeniem być wykorzystywane właśnie w charakterze sankcji ${ }^{14}$.

Administracyjne kary pieniężne są wymierzane w przypadkach enumeratywnie wskazanych w art. 298 ust. 1 ustawy Prawo ochrony środowiska. Z przepisu tego wynika, iż administracyjna kara pieniężna jest wymierzana za:

1. Przekroczenie ilości lub rodzajów gazów lub pyłów wprowadzanych do powietrza, które określają pozwolenia zintegrowane oraz pozwolenia na wprowadzanie pyłów lub gazów do powietrza, o których mowa w art. 181. ust. 1 pkt 1 i 2 ustawy;

2. Przekroczenie warunków dotyczących ilości ścieków, ich stanu, składu oraz minimalnej redukcji stężeń substancji w ściekach wyrażanej w procentach, a także masy substancji w ściekach odprowadzanych przypadającej na jednostkę masy wykorzystanego surowca, materiału, paliwa lub wytworzonego produktu, które określają pozwolenia zintegrowane oraz pozwolenia wodnoprawne na wprowadzanie ścieków do wód lub ziemi (art. 181 ust. 1 pkt 1 i 3);

3. Przekroczenie dopuszczalnej ilości obranej wody, określonej w pozwoleniach na pobór wody oraz w pozwoleniach zintegrowanych (art. 181 ust. 1 pkt 1);

4. Naruszenie warunków określonych w decyzji zatwierdzającej instrukcję prowadzenia składowiska odpadów lub w decyzji określającej miejsce oraz sposób ich magazynowania, które determinowane są przepisami ustawy o odpadach, co do rodzajów i sposobów ich składowania lub magazynowania;

5. Przekroczenie poziomów hałasu określonych w decyzji o dopuszczalnym poziomie hałasu lub w pozwoleniu zintegrowanym (art. 181 ust. 1 pkt 1).

14 Red. M. Górski, Prawo..., s. 145; pogląd odmienny reprezentuje W. Radecki, Optaty..., s. 43 i 44. 
Kara administracyjna jest wymierzana zatem w razie nieprawidłowego wykonywania przytoczonych decyzji wydanych na podstawie przepisów zawartych w ustawie Prawo ochrony środowiska oraz przepisów Konstytucji i niewątpliwie ma ona charakter kompensacyjny, jest bowiem konsekwencją szkodliwego oddziaływania na środowisko, jakie miało miejsce w wyniku naruszenia poziomów przewidzianych w odpowiednich pozwoleniach (pozwolenie zintegrowane, na wprowadzanie gazów lub pyłów do powietrza, pozwolenie wodnoprawne na wprowadzanie ścieków do wód i ziemi oraz pozwolenie wodnoprawne na pobór wód) oraz naruszenie warunków określonych w odpowiednich decyzjach (decyzja określająca instrukcję prowadzenia składowiska odpadów, decyzja określająca miejsce i sposób magazynowania odpadów, decyzja o dopuszczalnym poziomie hałasu). Podobny pogląd reprezentuje M. Lewicki, który twierdzi, iż „na gruncie regulacji administracyjno-prawnej sytuacja prawna podmiotów administrowanych determinowana jest zarówno bezpośrednio przepisami prawa powszechnie obowiązującego, jak i podejmowanymi na ich podstawie działaniami (zwłaszcza aktami administracyjnymi) organów administracji publicznej. W związku z tym sankcje nakładane są zarówno w konsekwencji naruszenia nakazów i zakazów wynikających bezpośrednio z przepisów prawnych, jak i aktów administracyjnych"15.

\section{KONTROLA I POSTĘPOWANIE W PRZEDMIOCIE WYMIERZENIA KARY}

W celu stwierdzenia naruszenia owych zakazów lub nakazów zgodnie z art. 299 ust. 1 ustawy Prawo ochrony środowiska organ uprawniony, a jest to wojewódzki inspektor ochrony środowiska, który działa w ramach Inspekcji Ochrony Środo-

15 M. Lewicki, Pojęcie sankcji prawnej $w$ prawie administracyjnym, PiP, 2002, nr 8, s. 69. 
wiska, przeprowadza kontrolę poprzez dokonanie pomiarów lub za pomocą innych środków dowodowych. Określenie „inne środki dowodowe" nie zostało przez ustawodawcę rozwinięte. W przypadku wymierzania administracyjnych kar pieniężnych zastosowanie ma przecież procedura administracyjna, a w Kodeksie postępowania administracyjnego ${ }^{16}$ znajdziemy cały rozdział poświęcony dowodom. Artykuł 75 k.p.a. zawiera definicję dowodu i zgodnie z tym przepisem, jako dowód należy dopuścić wszystko co może się przyczynić do wyjaśnienia sprawy, a co nie jest sprzeczne z prawem. W szczególności dowodem mogą być dokumenty, zeznania świadków, opinie biegłych oraz oględziny. Należy przyjąć, iż wszystko to może również stanowić dowód $\mathrm{w}$ postępowaniu administracyjnym w przedmiocie wymierzenia administracyjnej kary pieniężnej. Wojewódzki inspektor ochrony środowiska może też skorzystać z pomiarów dokonanych przez podmiot korzystający ze środowiska ${ }^{17}$, jeżeli jednak takie pomiary budzą wątpliwości organu, może on ich nie uznać ${ }^{18}$. Przepis art. 299 u.p.o.ś został tak sformułowany, iż budzi wątpliwości doktryny czy zawarte w obu punktach warianty środków dowodowych mogą być stosowane zamiennie, czy należy oba jednocześnie brać pod uwagę. Problem ten stał się również przedmiotem rozważań Naczelnego Sądu Administracyjnego (II OSK 574/05). Moim zdaniem nie powinno budzić wątpliwości umieszczenie w punkcie drugim możliwości skorzystania

16 Ustawa z dnia z dnia 14 czerwca 1960 r. Kodeks postępowania administracyjnego, Dz.U. 1960 nr 30 poz. 168 ze zm.

17 Zgodnie z art. 149 ust. 1 u.p.o.ś. podmiot prowadzący instalację i użytkownik urządzenia (chodzi np. o instalacje w zakresie wprowadzania gazów lub pyłów do powietrza) są zobowiązani do przestawienia wyników przeprowadzonych przez siebie pomiarów wojewódzkiemu inspektorowi ochrony środowiska, jeżeli pomiary te mają szczególne znaczenie ze względu na potrzebę zapewnienia systematycznej kontroli wielkości emisji lub innych warunków korzystania ze środowiska (szczegółowy zakres tego obowiązku znajduje się w rozporządzeniu Ministra Środowiska z dnia 19 listopada 2008 r. w sprawie rodzajów wyników pomiarów prowadzonych w związku z eksploatacją instalacji lub urządzeń i innych danych oraz terminów i sposobów ich prezentacji, Dz.U. z 2008 r. Nr 215, poz. 1366); definicja podmiotu korzystającego ze środowiska została ujęta w art. 3 pkt 20 u.p.o.ś.

18 Red. M. Górski, Prawo..., s. 157. 
z pomiarów przeprowadzanych przez podmioty korzystające ze środowiska jako wariantu alternatywnego. Przemawia za tym również sposób, w jaki został sformułowany art. 300 ustawy zgodnie, z którym decyzje ustalające wymiar kary biegnącej są ustalane po stwierdzeniu przekroczenia lub naruszenia, na podstawie kontroli, o której mowa w art. 299 ust. 1 pkt 1. Punkt drugi tego przepisu ma zatem charakter subsydiarny.

Postępowanie dotyczące wymierzenia administracyjnej kary pieniężnej jest dwuetapowe. Etap pierwszy obejmuje wymierzenie kary biegnącej, drugi natomiast kary „łącznej”. W pierwszym etapie zgodnie z art. 299 ust. 2 ustawy Prawo ochrony środowiska „o stwierdzeniu przekroczenia lub naruszenia na podstawie kontroli wojewódzki inspektor ochrony środowiska, w terminie 21 dni od wykonania pomiarów, zawiadamia podmiot korzystający ze środowiska przekazując mu wyniki pomiarów"19. Należy przyjąć, iż w razie, gdy wyniki kontroli będą wskazywały na przekroczenie norm określonych we właściwych pozwoleniach lub decyzjach wojewódzki inspektor ochrony środowiska wszczyna z urzędu postępowanie w przedmiocie wymierzenia kary pieniężnej. Jednakże jak wskazują R. Mikosz i G. Radecki określony w art. 299 ust. 2 dwudziestojednodniowy termin do zawiadomienia i przekazania wyników przeprowadzonych w ramach kontroli pomiarów podmiotowi korzystającemu ze środowiska ma charakter materialny, co oznacza, iż jego niezachowanie skutkuje niemożnością wszczęcia stosownego postępowania, a w konsekwencji wymierzenia kary pieniężnej $^{20}$, pomimo iż ustawodawca takiej sankcji nie przewidział. W tym momencie pojawia się istotny problem polegający na określeniu momentu, w którym zostaje wszczęte postępowanie w sprawie wymierzenia administracyjnej kary pieniężnej. Mając na względzie powyższe rozważania dotyczące wskazanego w ustawie terminu oraz jego charakteru zasadnym jest uznanie, iż postępowanie jest wszczynane z urzędu przez wojewódzki

19 Ibidem.

20 Por. R. Mikosz, G. Radecki, Leksykon opłat i kar pieniężnych związanych z korzystaniem ze środowiska, Wrocław 2010 s. 49; pogląd ten podzielił też K. Gruszecki, Komentarz..., s. 560, oraz W. Radecki, Opłaty i kary..., s. 127. 
inspektorat ochrony środowiska dopiero po przeprowadzeniu kontroli, a także po przekazaniu jej wyników podmiotowi korzystającemu ze środowiska. Taki pogląd reprezentuje K. Kwaśnicka: „należy przyjąć, że termin 21 dni nie został ustalony dla czynności następującej w konkretnym postępowaniu, lecz dla działania, które będzie stanowiło dopiero podstawę do wszczęcia postępowania"21. Odmienny pogląd natomiast reprezentują Z. Bukowski, E.K. Czech, K. Karpus, B. Rakoczy, twierdząc, iż przedmiotowe postępowanie zostaje wszczęte już w momencie podjęcia kontroli przez wojewódzkiego inspektora ochrony środowiska ${ }^{22}$. Jednak, aby wszcząć jakiekolwiek postępowanie, muszą zaistnieć przesłanki uzasadniające podjęcie stosownych działań. Taką przesłanką są niewątpliwie negatywne wyniki kontroli przeprowadzonej przez organ uprawniony, dają one legitymację do dalszego działania, jakim jest wydanie decyzji. Moim zdaniem samo przeprowadzenie kontroli nie wszczyna postępowania $\mathrm{w}$ sprawie wymierzenia kary biegnącej, $\mathrm{z}$ tego względu, iż wyniki kontroli mogą nie budzić żadnych zastrzeżeń. Poza tym ustawodawca nie uregulował w ustawie Prawo ochrony środowiska instytucji umorzenia postępowania, a niewątpliwie to należałoby zrobić, w sytuacji gdy postępowanie w sprawie wymierzenia kary wszczynane byłoby w momencie podjęcia kontroli, która z kolei nie wykryłaby żadnych naruszeń bądź przekroczeń.

W sytuacji, gdy wojewódzki inspektor ochrony środowiska w wyniku przeprowadzonej kontroli stwierdzi przekroczenie lub naruszenie limitów określonych we właściwych decyzjach, a następnie zachowując termin 21 dni zawiadomi o wynikach kontroli właściwy podmiot korzystający ze środowiska może dopiero przystąpić do wymierzenia temu podmiotowi administracyjnej kary pieniężnej. Kara wymierzana jest dwuetapowo ${ }^{23}$

21 K. Kwaśnicka, Odpowiedzialność..., s. 215.

22 Z. Bukowski, E. K. Czech, K. Karpus, B. Rakoczy, Prawo..., s. 547.

23 Wyjątkiem jest kara za przekroczenie ilości pobranej wody, którą wojewódzki inspektor ochrony środowiska wymierza na podstawie prowadzonych przez podmiot korzystający ze środowiska pomiarów. Zob. art. 307 ust. 1 u.p.o.ś oraz K. Kwaśnicka, Odpowiedzialność..., s. 215. 
w drodze decyzji, które są niewątpliwie decyzjami administracyjnymi w rozumieniu art. 104 k.p.a. Pierwszy etap postępowania w przedmiocie wymierzenia kary to ustalenie wymiaru kary biegnącej. Decyzja w tym przedmiocie musi zatem spełniać wymogi przewidziane dla decyzji administracyjnej, a ponadto wymogi, jakie przewidział dla niej ustawodawca w art. 300 ust. 4 pkt 1, 2, 3 ustawy Prawo ochrony środowiska. Decyzja powinna określać wielkość stwierdzonego przez organ naruszenia lub przekroczenia w skali doby bądź godziny ${ }^{24}$, wymiar kary biegnącej, a także termin, od którego będzie ona naliczana. Wskazuje się, że „W przypadku naruszającego warunki wskazane w stosownym pozwoleniu wprowadzania gazów lub pyłów do powietrza oraz poboru wód administracyjna kara pieniężna wymierzana jest w wysokości 10-krotnej wielkości jednostkowej stawki opłat. Za składowanie zaś odpadów z naruszeniem wymagań dotyczących składowania lub magazynowania odpadów WIOŚ wymierza karę w wysokości 0,1 stawki opłaty za umieszczenie odpadów na składowisku za każdą dobę składowania"25.

Ocenia się, iż „przyjąć należy, że decyzja ta ma charakter związany - w razie stwierdzenia przekroczeń lub naruszeń przy braku przesłanki negatywnej organ jest zobowiązany do wydania tego aktu"26. Wspomniana przesłanka negatywna została uregulowana w art. 308 ustawy Prawo ochrony środowiska. Wynika z niego, iż nie wszczyna się postępowania w sprawie wymierzenia kary, jeżeli jej przewidywana wysokość nie przekroczy 800 zł. Przepis ten potwierdza tylko tezę, iż postępowanie w sprawie wymierzenia administracyjnej kary pieniężnej wszczynane jest po przeprowadzeniu kontroli tj. po stwierdzeniu naruszeń lub przekroczeń, a nie w momencie jej rozpoczęcia. Ustawodawca nie określił natomiast terminu, w którym decyzja w przedmiocie wymierzenia kary biegnącej miałaby

24 Kara biegnąca może być karą dobową, jeżeli chodzi o zanieczyszczenia wód, odpady czy hałas. „Przy przekroczeniu ilości lub rodzaju gazów lub pyłów wprowadzanych do powietrza wymiar kary biegnącej określa się uwzględniając przekroczenie w skali godziny" - za M. Górski (red.), Prawo..., s. 157.

25 Red. M. Rudnicki, Organizacja ochrony środowiska, Lublin 2011, s. 178.

26 Z. Bukowski, E.K. Czech, K. Karpus, B. Rakoczy, Prawo..., s. 547. 
zostać wydana. Mając jednak na względzie zasady postępowania administracyjnego, organ powinien uczynić to bez zbędnej zwłoki, wnikliwie i szybko. Jeżeli chodzi natomiast o okres, na jaki decyzja w przedmiocie wymierzenia kary biegnącej jest wydawana zastosowanie ma art. 301 ust. 1, który stanowi iż kara biegnąca „biegnie” tzn. jest naliczana „do czasu stwierdzenia zmiany wielkości przekroczenia lub naruszenia", na zasadach określonych w art. 299 ust. 1 ustawy. Decyzja wojewódzkiego inspektora ochrony środowiska jest decyzją wydaną w pierwszej instancji, od której podmiotowi korzystającemu ze środowiska przysługuje odwołanie do Głównego Inspektora Ochrony Środowiska ${ }^{27}$. Jeżeli decyzja wydana w II instancji narusza prawo, podmiotowi przysługuje także skarga do sądu administracyjnego ${ }^{28}$.

Pomimo iż decyzja Głównego Inspektora Ochrony Środowiska jest ostateczna wymiar kary biegnącej może ulec zmianie na skutek wniosku złożonego przez podmiot korzystający ze środowiska (art. 301 ust. 1 u.p.o.ś.). W ciągu 30 dni od dokonania własnych pomiarów lub ustaleń wniosek powinien zostać przedłożony wojewódzkiemu inspektorowi ochrony środowiska. Warto zaznaczyć, iż zgodnie z ust. 4 komentowanego przepisu, ,jeżeli przekroczenie zostało stwierdzone na zasadach określonych w art. 299 ust. 1 pkt 1", pomiary niezbędne do przedłożenia wniosku powinny zostać przeprowadzone w tych samych miejscach oraz w sposób zgodny z pomiarami dokonanymi w ramach kontroli przeprowadzonej przez wojewódzkiego inspektora ochrony środowiska, który stwierdził przekroczenie.

27 „Nawet gdyby uznać, że sprawa przekroczenia lub naruszenia warunków decyzji jest sprawą szczególnie skomplikowaną, to w każdym razie wydanie decyzji powinno nastąpić nie później niż w ciągu 2 miesięcy od stwierdzenia przekroczenia lub naruszenia (art. $32 \S 3$ k.p.a.) (...) Jednakże uchybienie terminu zakreślonego w art. $35 \S 3$ k.p.a. nie powoduje wygaśnięcia możliwości (i obowiązku) wydania decyzji określającej wymiar kary biegnącej. (...) Główny Inspektor ma stosownie do art. $35 \S 3$ k.p.a. jeden miesiąc na rozpatrzenie odwołania, a niedotrzymanie tego terminu nie pociąga za sobą skutków materialnoprawnych." - cyt. za M. Górski, M. Pchałek, W. Radecki, J. Jerzmański, M. Bar, S. Urban, J. Jendrośka, Prawo ochrony środowiska. Komentarz, Warszawa 2011, s. 1070.

28 Ibidem, s. 1070. 
Jest to wymóg autentyczności pomiarów przeprowadzanych przez wnioskodawcę. W sytuacji, gdy inspektor nie zakwestionuje zasadności przedłożonego wniosku ustala on nowy wymiar kary biegnącej (również w drodze decyzji), która będzie naliczana od pełnej godziny lub doby od terminu, o którym mowa w art. 301 ust. 2 pkt 2. Natomiast sankcja za nierzetelne przeprowadzenie pomiarów może być dla podmiotu korzystającego ze środowiska niezwykle dotkliwa. W sytuacji bowiem stwierdzenia, że przekroczenie jest wyższe aniżeli podawane we wniosku lub nie ustało w przeciwieństwie do tego co twierdzi wnioskodawca ustala się na okres 60 dni nowy wymiar kary stosując dwukrotne zwiększenie stawki kary, a jej termin określa się począwszy od doby lub od godziny, w której wniosek został uznany za bezzasadny ${ }^{29}$. Na wydanie decyzji ustalającej nowy wymiar kary biegnącej jak też na ewentualne zakwestionowanie zasadności wniosku przedłożonego przez podmiot korzystające ze środowiska wojewódzki inspektor ochrony środowiska ma 30 dni (art. 301 ust. 5 u.p.o.ś.). Z uwagi na to, że jest to odrębna od poprzedniej decyzja, przysługuje od niej odwołanie do Głównego Inspektora Ochrony Środowiska oraz skarga do sądu administracyjnego ${ }^{30}$.

Nowy wymiar kary biegnącej jest ustalany w drodze decyzji administracyjnej również wtedy, gdy zmianie uległy stawki opłat za korzystanie ze środowiska stanowiących podstawę wymiaru kary (lub zmianie uległy stawki kar określonych w art. 310 ust. 2 i 311 ust. 2), a do dnia zmiany nie ustało stwierdzone naruszenie lub przekroczenie (art. 304 u.p.o.ś.). Wówczas „wojewódzki inspektor ochrony środowiska ustala w drodze decyzji nowy wymiar kary biegnącej, stosując nowe stawki od dnia ich wprowadzenia" (art. 304 u.p.o.ś). W przeciwieństwie do poprzedniego przypadku zmiany wymiaru kary biegnącej organ nie jest tu związany żadnym terminem. Mając jednak na względzie zasady dobrej administracji, należy przy-

29 A. Herma, Kary za niestosowanie się do reguł ochrony środowiska, http:// archiwum.parp.gov.pl/partnerinfo/przewodnik/13dz06.rtf, 13.05.2014 r.

30 J. Ciechanowicz-McLean, Z. Bukowski, B. Rakoczy, Prawo ochrony środowiska. Komentar\%, Warszawa 2008, s. 495. 
jąć, iż w przypadku zmiany stawek, o których mowa w art. 304 ustawy Prawo ochrony środowiska, nowa decyzja ustalająca winna być wydana niezwłocznie. Od takiej decyzji per analogiam również przysługuje odwołanie do Głównego Inspektora Ochrony Środowiska oraz skarga do sądu administracyjnego.

Postępowanie w przedmiocie decyzji ustalającej nowy wymiar kary biegnącej wszczynane jest na wniosek podmiotu, na który została nałożona kara w pierwotnym wymiarze. Wtedy też postępowanie było wszczynane przez organ z urzędu. Jak pisze K. Gruszecki przepis art. 301 u.p.o.ś. wykazuje pewną niekonsekwencję, bowiem ust. 2 mówi o tym, iż wymiar kary biegnącej może ulec zmianie na wniosek podmiotu korzystającego ze środowiska (postępowanie wszczynane na wniosek). W ustępie 1 natomiast znajduje się zapis, iż kara ta jest naliczana do czasu stwierdzenia, na zasadach określonych w art. 299 ust. 1, zmiany wielkości przekroczenia lub naruszenia ${ }^{31}$. Moim zdaniem należy przyjąć, że ustawodawca przewidział możliwość, w czasie tzw. „biegu” nałożonej kary pieniężnej, podjęcia z urzędu kontroli przez wojewódzkiego inspektora ochrony środowiska i w razie stwierdzenia zmiany wykrytych wcześniej przekroczeń lub naruszeń wydanie z urzędu decyzji ustalającej nowy wymiar kary biegnącej. Przemawia za tym niewątpliwie art. 154 k.p.a., który stanowi, że decyzja ostateczna, na mocy której żadna ze stron nie nabyła prawa, może być w każdym czasie uchylona lub zmieniona przez organ administracji publicznej, który ją wydał, jeżeli przemawia za tym interes społeczny lub słuszny interes strony. Poparcie takiego rozumowania znajduje się $\mathrm{w}$ art. 8 k.p.a., zgodnie, z którym organy administracji publicznej powinny prowadzić postępowania administracyjne w sposób budzący zaufanie jego uczestników do władzy publicznej. Podjęcie przez wojewódzkiego inspektora ochrony środowiska kontroli $\mathrm{W}$ ramach prewencji jest z pewnością działaniem zmierzającym do pogłębiania zaufania obywateli do organów administracji. Wątpliwości brak natomiast w drugim przypadku, w razie zmiany wysokości stawek opłat za korzystanie ze środowiska stano-

31 Por. K. Gruszecki, Prawo ochrony środowiska. Komentarz, Warszawa 2011, s. 564. 
wiących podstawę wymiaru kary. Decyzja w przedmiocie nowego wymiaru kary biegnącej jak już pisałam wyżej winna być wydana niezwłocznie.

Zgodnie z art. 302 ust. 1 u.p.o.ś. na podstawie ostatecznych decyzji określających wymiar kary biegnącej wojewódzki inspektor ochrony środowiska wydaje decyzję o wymierzeniu kary łącznej za okres do ustania przekroczenia lub naruszenia. Ustanie przekroczenia lub naruszenia stwierdza się z urzędu lub na wniosek podmiotu korzystającego ze środowiska i w razie złożenia takiego wniosku zastosowanie mają przepisy art. 301 ust. 2-5. Kara łączna może być wymierzona również za okres do dnia 31 grudnia każdego roku, jeżeli do tego czasu przekroczenie lub naruszenie nie ustało. Powyższy przepis reguluje drugi etap postępowania $\mathrm{w}$ sprawie wymierzenia administracyjnej kary pieniężnej tj. wydanie decyzji, która jak pisze Z. Bukowski, E.K. Czech, K. Karpus, B. Rakoczy jest decyzją wymiarową tzn. określającą ostateczną wysokość sankcji finansowej z tytułu przekroczeń lub naruszeń, o których mowa wyżej. Istnieje zatem ścisły związek pomiędzy decyzjami w przedmiocie nałożenia i wymiaru kary biegnącej a decyzją w przedmiocie kary łącznej. W tym miejscu należy odnieść się ponownie do przesłanki negatywnej wszczynania postępowania $\mathrm{w}$ sprawie wymierzenia podmiotowi korzystającemu ze środowiska administracyjnej kary pieniężnej. Jak słusznie zauważa K. Kwaśnicka, ustawodawca nie był odnośnie do tej regulacji precyzyjny tzn. brak określenia czy przesłanka negatywna z art. 308 u.p.o.ś. odnosi się do postępowania w sprawie wymiaru kary biegnącej czy też kary łącznej32. Jednakże przepis ten stanowi, iż nie wszczyna się postępowania w sprawie wymierzenia kary, jeżeli jej przewidywana wysokość nie przekroczy 800 zł. Z racji tego, iż kara biegnąca jest naliczana do czasu ustania naruszenia lub przekroczenia ciężko stwierdzić na początku jej „biegu”, jak długo będzie naliczana, a w konsekwencji, jaka będzie jej ostateczna wysokość. W ocenie cytowanych wyżej autorów „z uwagi na konstrukcję postępowania, obejmującą etap wydania decyzji ustalającej wymiar

32 K. Kwaśnicka, Odpowiedzialność..., s. 216 i 217; patrz też. K. Gruszecki, Prawo..., s. 584. 
kary biegnącej (art. 300 ust. 1) oraz etap wydania na podstawie ostatecznych decyzji określających wymiar kary biegnącej decyzji o wymierzeniu kary (art. 302 ust. 1), przyjąć należy, że art. 308 znajdzie zastosowanie tylko w przypadku, gdy po przeprowadzeniu kontroli organ ustalił, że próg 800 zł nie zostanie przekroczony w przypadku kary, o której mowa w art. 302 ust. 1 komentowanej ustawy"33. W związku z powyższym negatywna przesłanka wszczynania postępowania w sprawie wymierzenia administracyjnej kary pieniężnej będzie miała większe zastosowanie w stosunku do kary łącznej a nie kary biegnącej. Istotną kwestią jest czy w przypadku, gdy ta przesłanka znajduje zastosowanie organ jest zobligowany do wydania jakiejś decyzji.

\section{ODROCZENIE KARY}

W ustawie Prawo ochrony środowiska została uregulowana instytucja będąca przedmiotem częstej praktyki w związku z nakładaniem administracyjnych kar pieniężnych. Podmiot korzystający ze środowiska oprócz tego, że przysługuje mu prawo złożenia wniosku o zmianę wymiaru kary biegnącej (art. 301 u.p.o.ś.), może także wystąpić z wnioskiem o odroczenie kary łącznej. Przesłanką odroczenia kary jest realizowanie przez dany podmiot przedsięwzięcia ${ }^{34} \mathrm{w}$ okresie nie dłuższym niż 5 lat od dnia złożenia wniosku, którego wykonanie zapewni usunięcie przyczyn nałożenia kary (przykładowo instalowanie nowych, mniej uciążliwych dla środowiska urządzeń, zakładanie urządzeń ochronnych bądź wprowadzanie nowych technolo-

33 Z. Bukowski, E.K. Czech, K. Karpus, B. Rakoczy, Prawo..., s. 557.

34 Definicję przedsięwzięcia art. 3 ust. 1 pkt 13 u.u.i.ś., zgodnie, z którym jest to zamierzenie budowlane lub inna ingerencja w środowisko, polegająca na przekształceniu lub zmianie sposobu wykorzystania terenu, w tym również na wydobywaniu kopalin. Pomimo tego, iż definicja ta jest definicją szczególną, w literaturze przyjmuje się, że może mieć ona także zastosowanie do postępowania o odroczenie płatności opłat podwyższonych i administracyjnych kar pieniężnych, patrz K. Gruszecki, Prawo..., s. 598. 
gii) ${ }^{35}$. Uregulowany w dziale IV tytule V u.p.o.ś. instrument odroczenia nałożonej kary daje szansę podmiotom korzystającym ze środowiska, które dążą do usunięcia ich przyczyn, realizacji powziętych zamierzeń poprzez nieobciążanie tych podmiotów dodatkowymi kosztami, co niewątpliwie by realizację owych zamierzeń utrudniło.

Ciekawy pogląd na temat charakteru odroczenia kary wyraził B. Draniewicz ${ }^{36}$, a także J. Ciechanowicz-McLean, Z. Bukowski oraz B. Rakoczy twierdząc, że odroczenie kary pieniężnej jest to sui generis środek probacyjny, który zawiera elementy charakterystyczne dla poddania sprawcy próbie. Nie sposób się z tym nie zgodzić, ponieważ w razie „pomyślnego przejścia okresu próby” podmiot korzystający ze środowiska spotka „nagroda” w postaci braku konieczności płacenia uprzednio wymierzonej kary pieniężnej37.

Zgodnie z art. 316 u.p.o.ś. podmiotem uprawnionym do odroczenia administracyjnej kary pieniężnej jest wojewódzki inspektor ochrony środowiska, a decyzja w przedmiocie odroczenia wydawana jest na wniosek zainteresowanego pomiotu złożony przed upływem terminu, w którym kara miała być uiszczona (art. 318 u.p.o.ś.), a nie z urzędu. Przyjmuje się, iż odroczenie następuje $\mathrm{w}$ drodze decyzji administracyjnej tak samo jak nałożenie kary biegnącej oraz kary łącznej. Jak pisałam wyżej, warunkiem odroczenia kary jest terminowe realizowanie przedsięwzięcia, którego wykonanie zapewni usunięcie przyczyn ponoszenia podwyższonych opłat albo kar w okresie nie dłuższym niż 5 lat od dnia złożenia wniosku (art. 317 ust. 1 u.p.o.ś). Jeżeli natomiast przedsięwzięcie zapewniające usunięcie przyczyn ponoszenia podwyższonych opłat lub kar, jest ujęte w krajowym programie oczyszczania ścieków komunalnych ${ }^{38}$,

35 K. Kwaśnicka, Odpowiedzialność..., s. 217.

36 Por. B. A. Draniewicz, Opłaty za korzystanie ze środowiska. Zarys analizy płaszczyzny prawnej, „Prawo i Środowisko” 2002, nr 1, za: K. Kwaśnicka, Odpowiedzialność..., s. 217.

37 K Kwaśnicka, Odpowiedzialność..., s. 217.

38 O krajowym programie oczyszczania ścieków komunalnych mówi art. 43 ust. 3 ustawy z dnia 18 lipca 2001 r. Prawo wodne. Sporządza go Prezes Krajowego Zarządu Gospodarki Wodnej, zatwierdza Rada Ministrów. 
termin płatności również odracza się na wniosek podmiotu korzystającego ze środowiska (art. 317 ust. 1a). Odroczenie może dotyczyć całości lub części opłaty lub kary (art. 317 ust. 2). Jak pisze K. Gruszecki, instytucja ta w całości będzie miała zastosowanie jedynie do kar $^{39}$. Doktryna prawa ochrony środowiska wyraża pogląd, iż decyzja w przedmiocie odroczenia kary jest decyzją związaną tzn. organ jest zobowiązany do jej wydania w sytuacji, gdy podmiot, na który nałożono karę złoży stosowny wiosek, a organ poczyni właściwe ustalenia czy warunki uzasadniające odroczenie zostały spełnione ${ }^{40}$. W razie braku spełnienia wymaganych warunków organ powinien wydać decyzję o odmowie odroczenia kary.

Wydając decyzję o odroczeniu kary organ określa karę, bądź opłatę, której termin płatności został odroczony, wysokość kary oraz realizowane przedsięwzięcie wraz z harmonogramem (art. 317 ust. 5 u.p.o.ś.). Jak pisze K. Gruszecki termin określony w decyzji i odroczeniu może być na wniosek podmiotu zainteresowanego zmieniany w trybie art. 155 k.p.a., nie może on jednak być dłuższy niż w skazane w art. 317 u.p.o.ś. 5 lat. Termin ten jest bowiem terminem materialnym i nie może być przekroczony. Wniosek o zmianę terminu powinien zostać złożony przed upływem terminu pierwotnego. Zgodnie z art. 319 jeżeli terminowe wykonanie zamierzonego przedsięwzięcia usunęło przyczyny dla których na podmiot korzystający ze środowiska została nałożona kara organ, ponownie w drodze decyzji, orzeka o jej zmniejszeniu o sumę środków własnych, które podmiot wydał na realizację przedsięwzięcia. Jeżeli natomiast przedsięwzięcie służy realizacji zadań własnych gminy, do środków własnych wlicza się również środki pochodzące z budżetu gminy. Do kwoty, która pozostała do zapłaty, stosuje się przepisy działu III ustawy Ordynacja podatkowa dotyczące opłaty prolongacyj-

Określa on w szczególności zakres rzeczowo-finansowy przedsięwzięć i termin ich zakończenia.

39 K. Gruszecki, Prawo..., s. 597.

40 Z. Bukowski, E. K. Czech, K. Karpus, B. Rakoczy, Prawo..., s. 575. 
nej ${ }^{41}$. Jeżeli kara dotyczyła przekroczenia określonych w decyzji warunków odnośnie składowania odpadów, a podmiot terminowo zrealizował przedsięwzięcie, organ stwierdza umorzenie kary (art. 319 ust. 3). Ocenia się, że „wolą ustawodawcy jest to, aby stosowanie komentowanej regulacji stymulowało zachowania podmiotów tak, aby ich zachowania przyniosły im efekty bezpośrednio o charakterze ekonomicznym, dla środowiska zaś realne w postaci realizacji inwestycji skutkującej usunięciem przyczyn ponoszenia wskazywanych obowiązków"42. Te ekonomiczne efekty to zmniejszenie lub umorzenie odroczonych kar administracyjnych. Ustawodawca przewidział jednak, że nawet terminowe zrealizowanie przedsięwzięcia może nie przynieść zamierzonego efektu, tzw. niepomyślne zakończenie okresu próby - „wprawdzie przedsięwzięcie zostało zrealizowane terminowo, ale nie usunęło przyczyny podwyższenia opłaty lub nałożenia kary"43. Organ jest wtedy zobligowany do wydania decyzji w przedmiocie obowiązku uiszczenia odroczonej kary lub opłaty wraz z opłatą prolongacyjną (art. 319 ust. 4). Opłatą prolongacyjną określa się opłatę za przedłużenie, przesunięcie, odroczenie terminu płatności lub wykonania czegoś. Stanowi ona swojego rodzaju oprocentowanie. Okres próby zakończy się niepomyślnie dla podmiotu korzystającego ze środowiska również wtedy, gdy przedsięwzięcie mające na celu usunięcie przyczyn nałożenia na podmiot administracyjnej kary pieniężnej nie zostanie zrealizowane $\mathrm{w}$ terminie (art. 320 ust. 1) lub organ stwierdzi, że przedsięwzięcie nie jest realizowane zgodnie z harmonogramem (art. 320 ust. 2). Organ niewątpliwie może to stwierdzić na podstawie informacji o przebiegu realizacji przedsięwzięcia jakie podmiot korzystający ze środowiska jest z obligowany mu przedstawiać nie rzadziej niż raz na 6 miesięcy (art. 318a). Wojewódzki inspektor ochrony środowiska wydaje wtedy decyzję o obowiązku uiszczenia odroczonych opłat lub kar wraz z określonymi w przepisach Ordynacji podatkowej

41 Ordynacja podatkowa z dnia 29 sierpnia 1997 r., Dz.U. 1997, nr 137, poz. 926.

42 Z. Bukowski, E. K. Czech, K. Karpus, B. Rakoczy, Prawo..., s. 583.

43 W. Radecki, Optaty..., s. 158. 
odsetkami. Odsetki w tym przypadku ustala się od orzeczonej kary ${ }^{44}$. W razie odroczenia terminu płatności administracyjnej kary pieniężnej stosuje się odpowiednio również przepisy Ordynacji podatkowej w zakresie wstrzymania biegu terminu przedawnienia należności. Zgodnie z art. $70 \S 2$ pkt 1 Ordynacji bieg terminu przedawnienia nie rozpoczyna się, a rozpoczęty ulega zawieszeniu od dnia wydania decyzji do dnia odroczonego terminu płatności.

Przy okazji odraczania kar łącznych oraz opłat podwyższonych pojawiły się $\mathrm{w}$ doktrynie prawa ochrony środowiska dwa istotne zagadnienia. Pierwsze z nich dotyczy sytuacji, w której podmiot korzystający ze środowiska ukończy inwestycję, która zniweluje przyczyny nałożenia administracyjnej kary pieniężnej jeszcze przed złożeniem wniosku o jej odroczenie. Przypomnijmy, że termin do złożenia wniosku został przez ustawodawcę określony bardzo nieprecyzyjnie (wniosek powinien zostać złożony przed upływem terminu, w którym kara miała zostać uiszczona). Jak pisze K. Gruszecki, niejasne jest, „czy podstawą do wydania decyzji odraczającej termin płatności kary pieniężnej lub części opłaty podwyższonej może być tylko zamierzenie, które dopiero ma zostać zrealizowane, czy też w pewnych sytuacjach również takie, które już zostało zrealizowane"45. Jednakże zgodnie z przepisem art. 317 ust. 4 ustawy Prawo ochrony środowiska, termin płatności może być odroczony wyłącznie na okres niezbędny do realizacji przedsięwzięcia, o którym mowa w ust. 1 lub 1a tegoż przepisu. A zatem, jeżeli przedsięwzięcie zostałoby zrealizowane przed wymierzeniem kary łącznej to jej odroczenie nie miałoby uzasadnienia ${ }^{46}$. Co więcej, wymierzanie kary łącznej byłoby w ogóle zbędne. Nie sposób nie zgodzić się ze stanowiskiem Wojewódzkiego Sądu Administracyjnego za-

44 Rozporządzenie Ministra Finansów z 22 sierpnia 2005 r. w sprawie naliczania odsetek za zwłokę oraz opłaty prolongacyjnej, a także zakresu informacji, które muszą być zawarte na rachunkach, (Dz.U. nr 165, poz. 1373 ze zm.).

45 K. Gruszecki, Prawo..., Warszawa 2011, s. 600.

46 W. Radecki, Komentarze do ustawy - Prawo ochrony środowiska. Środki finansowo-prawne. Tytuł V ustawy-Prawo ochrony środowiska, Wrocław 2002, s. 110, za: K. Gruszecki, Prawo..., s. 600. 
prezentowanym w wyroku z dnia 11 maja 2005 r. ${ }^{47}$, w którym sąd stanął na stanowisku, iż podmiot, który realizuje odpowiednie przedsięwzięcia, usuwając $w$ ten sposób przyczyny wymierzenia mu kary za uprzednie naruszenie wymagań ochrony środowiska, nie może być traktowany gorzej aniżeli podmiot, który od realizacji takich przedsięwzięć się powstrzymywał i czekał na wymierzenie mu kary. Stanowisko takie jest wielce uzasadnione, gdyż podmioty, którym naliczana jest kara biegnąca mogą w tym czasie zrealizować inwestycje, które zniwelują przyczyny jej nałożenia. Nie jest zasadnym, aby taki podmiot ponosił negatywne konsekwencje takiego działania, jeżeli działa z korzyścią dla środowiska. Jego sytuacja nie może być gorsza niż sytuacja podmiotu reprezentującego bierną postawę.

Kolejnym zagadnieniem jest wykonanie przez podmiot, który ubiegał się o odroczenie administracyjnej kary pieniężnej innego przedsięwzięcia aniżeli pierwotnie zamierzone, jeżeli to inne przedsięwzięcie usunęło przyczyny nałożenia na podmiot administracyjnej kary pieniężnej. Z. Bukowski, E.K. Czech, K. Karpus oraz B. Rakoczy zwracają uwagę na to, iż przedmiotem oceny w sprawie wydania decyzji o odroczeniu terminu płatności administracyjnej kary pieniężnej czy też opłaty podwyższonej nie powinna być inwestycja z punktu widzenia prawa budowlanego, lecz efekt finalny dla ochrony środowiska. Co więcej, przepisy dotyczące odraczania kar i opłat „nie przewidują, jako przesłanki do stosowania określonych tam konsekwencji do podmiotu, który dokonał zmian w procesie inwestycyjnym"48. Za takim rozumowaniem przemawia także wyrok Naczelnego Sądu Administracyjnego w Warszawie z 30 listopada 2000 r. ${ }^{49}$ Sąd w uzasadnieniu zauważył, iż „każda inwestycja, która doprowadziła w okresie odroczenia kary do usunięcia przyczyn jej wymierzenia, wyłącza możliwość zastosowania przez organy ochrony środowiska sankcji wynikającej $\mathrm{z}$ art. 110c ust. 6 ustawy z dnia 31 stycznia 1980 r. o ochronie i kształtowaniu środowiska (...)". Natomiast Naczelny Sąd Administracyj-

47 IV SA/Wa 10/05, CBOSA.

2/2014

48 Z. Bukowski, E. K. Czech, K. Karpus, B. Rakoczy, Prawo..., s. 584.

49 IV SA 1340/98, ONSA 2002, nr 2, poz. 70. 
ny w wyroku z dnia 11 maja 1999 r. podkreślił, iż „podstawę uwzględnienia wniosku o odroczenie mogą stanowić tylko te przedsięwzięcia, których realizacja zapewni usunięcie przyczyn ponoszenia opłat podwyższonych lub kar pieniężnych"50. Należy jednak pamiętać, że podmiot korzystający ze środowiska jest związany decyzją wydaną przez wojewódzkiego inspektora ochrony środowiska w przedmiocie odroczenia nałożonej kary łącznej, a także harmonogramem wykonania przedsięwzięcia, które ma doprowadzić do usunięcia przyczyn nałożenia kary. Co więcej podmiot korzystający ze środowiska zobligowany jest do informowania organu o postępach $\mathrm{w}$ realizacji przedsięwzięcia przynajmniej raz na 6 miesięcy. Jeżeli w toku realizacji przedsięwzięcia okaże się, że jest ona niemożliwa do wykonania lub nie przyniesie zamierzonego efektu (korzystnego dla środowiska) zmiana $\mathrm{w}$ przedmiocie inwestycji powinna nastąpić poprzez zmianę decyzji, analogicznie do zmiany terminu potrzebnego na jej realizację.

\section{PODSUMOWANIE}

Administracyjne kary pieniężne odgrywają $\mathrm{w}$ prawie ochrony środowiska istotną rolę. Stanowią nie tylko sankcję dla podmiotu korzystającego ze środowiska, ale również stymulują rozwój inwestycji, które mają zapobiegać negatywnemu oddziaływaniu na środowisko. Instytucja odroczenia kary stanowi dla podmiotu swoisty okres próby i szansę na uniknięcie płacenia wysokich sum za nieprzestrzeganie wymagań określonych w odpowiednich decyzjach lub pozwoleniach. Mówiąc kolokwialnie, ustawodawca przewidział możliwość poprawy, która pozwala uniknąć kary, pozytywnie wpływa na środowisko oraz stymuluje rozwój przedsiębiorstw, gdyż to one w większości są podmiotami, na które nakładane są administracyjne kary pieniężne.

50 Wyrok NSA 11 maja 1999 r. IV SA 772/97. 


\section{BIBLIOGRAFIA}

Bukowski Z., Czech E. K., Karpus K., Rakoczy B., Prawo ochrony środowiska, Komentarz, Warszawa 2013.

Ciechanowicz-McLean J., Ochrona środowiska $w$ działalności gospodarczej, Warszawa 2003.

Draniewicz B. A., Opłaty za korzystanie ze środowiska. Zarys analizy płaszczyzny prawnej, „Prawo i Środowisko” 2002, nr 1.

Górski M. (red.), Prawo ochrony środowiska, Warszawa 2014.

Górski M., Pchałek M., Radecki W., Jerzmański J., Bar M., Urban S., Jendrośka J., Prawo ochrony środowiska. Komentarz, Warszawa 2011.

Gruszecki K., Prawo ochrony środowiska. Komentarz, Warszawa 2011.

Kwaśnicka K., Odpowiedzialność administracyjna w prawie ochrony środowiska, Warszawa 2011.

Lang W., Struktura odpowiedzialności prawnej, „Zeszyty Naukowe Uniwersytetu Mikołaja Kopernika", z. 31 - Prawo VIII, Torun 1968.

Lewicki M., Pojęcie sankcji prawnej $w$ prawie administracyjnym, PiP, 2002, nr 8.

Lipiński A., Prawne podstawy ochrony środowiska, Kraków 2005.

Mikosz R., Radecki G., Leksykon opłat i kar pieniężnych związanych z korzystaniem ze środowiska, Wrocław 2010.

Radecki W., Komentarze do ustawy - Prawo ochrony środowiska. Środki finansowo-prawne. Tytut V ustawy - Prawo ochrony środowiska, Wrocław 2002.

Radecki W., Optaty i kary pieniężne $w$ prawie ochrony środowiska. Komentarz do przepisów ustaw, Warszawa 2009.

Rudnicki M. (red.), Organizacja ochrony środowiska, Lublin 2011.

Stelmasiak J. (red.), Prawo ochrony środowiska, Warszawa 2009.

Stelmasiak J., Popik-Muzyka K., Administracyjna kara pieniężna $w$ ustawie - Prawo ochrony środowiska, „Ochrona Środowiska. Przegląd" 2002, nr 1.

Tyszkiewicz L., Problem odpowiedzialności karnej osób prawnych (zakładów pracy) $w$ polskim systemie prawnym, „Prace Naukowe Uniwersytety Śląskiego", nr 54, Katowice 1974.

\section{Kontakt e-mail}

a.kudrzycka@wp.pl 